doi:10.4149/neo_2014_016

\title{
Over-expression of LGR5 correlates with poor survival of colon cancer in mice as well as in patients
}

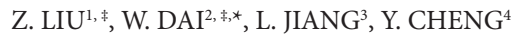

${ }^{1}$ Division of gastroenterology, the Third Affiliated Hospital, Sun Yat-Sen university, Guangzhou, China; ${ }^{2}$ Division of gastrointestinal surgery, the First Affiliated Hospital, Sun Yat-Sen university, Guangzhou, China; ${ }^{3}$ Division of Urological oncology, Cancer Center, Sun Yat-Sen university, Guangzhou, China; ${ }^{4}$ Division of Cardiology, the First Affiliated Hospital, Sun Yat-Sen university, Guangzhou, China

${ }^{*}$ Correspondence: professorliujun163.com

${ }^{*}$ Contributed equally to this work.

Received April 15, 2013 / Accepted August 8, 2013

\begin{abstract}
Leucine-rich repeat-containing G protein-coupled receptor 5 (LGR5) was identified as the stem cell marker of colon cancer stem cells (CSCs), which were considered as the main criminal cells initiation and reinitiation of colon cancer. We intended to demonstrate and further explain the relationship between LGR5 and colon cancer in mice model and patients. In our research, we used transcriptional methods and immunohistochemistry to investigate the LGR5 gene and protein expression, examined proliferating cell nuclear antigen (PCNA) and Ki67 which were the classic markers for cell proliferation in LGR5 protein positive and negative colon cancer among mice model and patients. Our results showed that LGR5 mRNA and protein expression was significantly over-expressed in 193/366 patients and 24/40mice model with primary colon cancer contrasted with matched normal tissues; significantly higher LGR5 gene expression was detected in pT4 cases than that in pT3 cases; PCNA and Ki67 expression was much more increase in colon cancer cells with positive LGR5 expression than those with negative LGR5 expression;LGR5 positive cancer not only in mice model but also in patients have shorter survival rate compared with LGR5 negative cancer. All our study manifested that LGR5 took on an important effect in the initiation and progression of colon cancer, provided also more helpful evidence for clinical diagnosis and an useful indicator for adjuvant therapy.
\end{abstract}

Key words: LGR5, colon cancer, survival rate

Colon cancer is one of the most common malignant cancer in the gastrointestinal tract around the world $[1,2]$. The current therapeutic protocols for colon cancer patients include advanced surgical techniques, adjuvant Chemotherapy, radiotherapy and molecular biological agents. After curative therapy, a large proportion of patients remain clinically free of disease for months or years. However, after such period of remission, colon cancer relapses in about $30 \%-50 \%$ of all cases, which mostly happen in the regional and also distant sites. Statistical analysis reports revealed that patients with localized cancer had approximately $90 \% 5$-year survival rate whereas those with regional or distant cancer dissemination had less than $60 \%$ or $12 \%$ respectively $[3,4]$. Although death

Abbreviations: LGR5:Leucine-rich repeat-containing G protein-coupled receptor 5, CSCs: colon cancer stem cells, PCNA: proliferating cell nuclear antigen, AOM : azoxymethane, $\mathrm{MN}$ : matched normal, CA: carcinoma caused by colon cancer are mainly due to recurrent tumors , the biological pathology of disease relapse remains to be elusive. Previous studies have suggested that a small proportion of cell subpopulations involved in primary colon cancer are capable of reproducing a tumor, which are the main culprits of neoplasm recurrence after it is removed $[5,6]$. The unique characteristic of the principal criminal cells called colon cancer stem cell (CSC) for reinitiation of intestinal neoplasm is the stemness property. Many researches have found that CSCs have been isolated from different tumors including colorectal cancer and can form intact neoplasm after implanted underneath the skin of immunity-insufficient mice [7-9]. With progression of researches on CSC for a period of time, features and plenty of biomarkers of colon CSCs have been identified, but there still has no effective therapy to entirely compromise on colon CSCs. Therefore, finding potential and effective biomarkers targeting subpopulations 
of rapidly growing, differentiated tumor cells such as CSCs for improving the outcomes of carcinoma becomes more urgent in anti-carcinoma battle.

Leucine-rich repeat-containing $\mathrm{G}$ protein-coupled receptor 5(LGR5), is a member of G-protein-coupled receptor (GPCR) family of proteins and is a regulated target of Wnt signaling [10-12]. In 2007, LGR5 was found to express restricted in the crypt base of small and large intestines and was identified as the stem cell marker for cells capable of committed differentiation $[13,14]$. Numerous studies have demonstrated that LGR5 protein has close association with initiation and recurrence of different cancer types [15-17]. LGR5 protein was over-expressed in hepatocellular carcinoma, colorectal cancer, ovarian cancer, basal cell carcinoma and esophageal adenocarcinoma. Moreover, crypt LGR5 ${ }^{+}$stem cells in intestine have been observed to be represented as the cell of origin for intestinal cancer [18].

Table 1. Clinicopathological characteristics of patients with LGR5 positive and negative cancer.

\begin{tabular}{|c|c|c|c|c|}
\hline \multirow{2}{*}{$\begin{array}{l}\text { Clinicopathology } \\
\text { and Characteristic }\end{array}$} & \multirow[t]{2}{*}{ Total } & \multicolumn{3}{|c|}{ LGR5 protein } \\
\hline & & $\begin{array}{c}\text { Positive } \\
\mathrm{n}(\%)\end{array}$ & $\begin{array}{c}\text { Negative } \\
\mathrm{n}(\%)\end{array}$ & $P$-value \\
\hline Total N & 366 & 193(53) & $173(47)$ & \\
\hline $\operatorname{Age}(\operatorname{mean} \pm \mathrm{SD})$ & $59 \pm 8.56$ & $60 \pm 5.83$ & $58 \pm 8.53$ & \\
\hline Age, n(\%) & & & & 0.824 \\
\hline$<65$ & 193 & 95 & 98 & \\
\hline$\geq 65$ & 173 & 78 & 95 & \\
\hline Gender & & & & 0.554 \\
\hline male & 200 & 98 & 102 & \\
\hline Female & 166 & 80 & 86 & \\
\hline Tumor location & & & & 0.712 \\
\hline Right colon & 180 & 89 & 91 & \\
\hline Left colon & 186 & 95 & 91 & \\
\hline T category & & & & $0.035^{\star}$ \\
\hline $\mathrm{pT} 1$ & 75 & 12 & 16 & \\
\hline pT2 & 69 & 25 & 22 & \\
\hline pT3 & 100 & 30 & 70 & \\
\hline pT4 & 122 & 82 & 40 & \\
\hline $\mathrm{N}$ category & & & & $0.045^{*}$ \\
\hline 0 & 120 & 90 & 130 & \\
\hline 1 & 147 & 85 & 62 & \\
\hline 2 & 99 & 67 & 32 & \\
\hline Distant metastasis & & & & $0.050^{*}$ \\
\hline Absent & 245 & 100 & 145 & \\
\hline Present & 121 & 89 & 32 & \\
\hline Differentiation & & & & 0.060 \\
\hline Well/moderate & 214 & 80 & 134 & \\
\hline Poor & 149 & 102 & 47 & \\
\hline Not available & 3 & 0 & 3 & \\
\hline Chemotherapy & 169 & 84 & 85 & 0.239 \\
\hline Recurrence & 95 & 43 & 52 & 0.318 \\
\hline
\end{tabular}

${ }^{*} p<0.05$ compared between LGR5+and LGR5-group
Mouse LGR $5^{+}$cells in intestinal crypt give rise to intestinal tumors with more inclining and higher efficiency than other intestinal epithelial cell populations upon mutational activation of the Wnt pathway. All these results show that LGR5 is a potential biomarker for colon cancer stem cell. Thereby, we used transcriptional methods and immunohistochemistry to investigate the LGR5 gene and protein expression in mice and patients colon cancer. In this study, we detected the possible function of LGR5 expression in clinical progression and prognosis,and examined proliferating cell nuclear antigen (PCNA) and Ki67, which were the classic markers for cell proliferation in LGR5 protein positive and negative colon cancer respectively, in mice model and patients. We hope to provide more helpful information for clinical diagnosis and management of colon cancer.

\section{Patients and methods}

Patients and samples. The main characteristics of inclusive patients are presented in Table 1.From 2002 to 2012,366 patients with colon cancer were performed surgical resections at department of digestive surgery, DongShan division of the first affiliated hospital of Sun Yat-Sen university of China. These patients comprised 200 males and 166 females, average

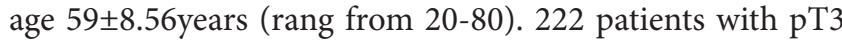
or T4 were carried out with curative operations.121 patients were found with distant metastases including liver and lymph node. 169 patients had received pre-operative chemotherapy. We separated all patients into LGR5 positive and negative groups and compared them clinicopathologically. Surgically excised specimens of cancerous tissue and matched normal mucosal tissue were obtained from all patients with operation for immunohistochemistry and quantitative reverse transcription-polymerase chain reaction (qRT-PCR) analysis. All samples were taken from surgically resected material,then immediately frozened in liquid nitrogen and stored at $-80^{\circ} \mathrm{C}$, a pathological diagnosis was made according to the TMN classification. None of all patients had synchronous cancers and ulcerative colitis. The study protocol was approved by the ethical committee of the First Affiliated Hospital of Sun Yat-Sen University (Guangzhou, China). All patients were followed up for survival analysis. By April 2013 (the time of data collection), 235patients died and 131 were alive. The median survival time was 65 months.

Mice and treatment. Six to ten-weeks-old C57/BL6 55 littermates were injected i.p. with a single dose of (azoxymethane, AOM) (sigma; $10 \mathrm{mg} / \mathrm{Kg}$ ) or saline (control) once a week for 6 weeks. 40 of 45 mice which received AOM treatment developed colon tumors and died within 10 months following injections. 24 of 40 mice with primary tumors was found to have LGR5 protein expression. Tissues were fixed in Formalin for 24 hours for immunohistochemistry. The procedures in mice experiments were approved by the institutional animal and use committee at the first affiliated hospital of Sun YatSen university. 
Quantitative RT-PCR. Total RNA was extracted from colon cancer and matched tissues obtained from patients and mice model using TRlzol reagent (invitrogen, USA). cDNA was synthesized using Ominiscript reverse transcriptase (Roche, USA) under following conditions: $37^{\circ} \mathrm{C}$ for $1 \mathrm{~h}$ and $94^{\circ} \mathrm{C}$ for $5 \mathrm{~min}$. The cDNA was diluted 1:10 using diethyl pyrocarbonate water, and the real-time $\mathrm{PCR}$ reaction solution consisted of 5ul cDNA, 12.5ul QuantiTest SYBR Green PCR kit (Roche, USA), 5.5ul diethyl pyrocarbonate water, and 1ul forward and reverse primer $(20 \mathrm{pmol})$ for a final reaction volume of $25 \mathrm{ul}$. The primer sequences are presented in Table 2. Quantitative real-time PCR analysis was performed on an Applied Biosystem 7500 real-time PCR machine(Applied Biosystem, USA) using the following conditions: $50^{\circ} \mathrm{C}$ for $2 \mathrm{~min}, 94^{\circ} \mathrm{C}$ for $10 \mathrm{~min}$, and 40 cycles of $94^{\circ} \mathrm{C}$ for $10 \mathrm{~s}$ and $60^{\circ} \mathrm{C}$ for $1 \mathrm{~min}$. LGR5 expression was normalized to GAPDH. All experiments were performed in triplicate and repeated in at least three separate experiments; representative data from these experiments are presented.

Immunohistochemical analyses. For immunohistochemistry, tumors and matched normal colonic mucosal tissues were analyzed in patients's specimen and mice cancer. Formalin-fixed and paraffin-embeded sections were incubated with LGR5 monoclonal antibody (1:100; AP2745a, Abgent) for overnight at $4^{\circ} \mathrm{C}$ for detection of LGR5 expression. The sections were then incubated with anti-rabbit Secondary antibody (Santa Cruze, USA). Using 3,3'-Diaminobenzidine as the chromogen. Negative controls were also run simultaneously. LGR5 expression was accessed qualitatively in a blinded fashion without knowledge of clinical and pathological information. The sections were counterstained with hematoxylin and mounted.

Western blotting. Total protein extracts were purified and analyzed by electrophoresis as previously described [19]. An aliquot (50ug) of sample proteins were denatured in sample buffer containing SDS and $\beta$-mercaptoethanol, separated on a $6 \%-20 \%$ gradient SDS-PAGE gel, and electroblotted onto nitrocellulose membranes. Nonspecific binding sites of the membranes were blocked using defatted milk proteins followed by the addition of antibodies including PCNA (sc7907, Santa Cruz, USA) and $\beta$-actin (Santa Cruz, USA). The relative amount of primary antibody was detected with per- oxidase-conjugated secondary antibody including anti-rabbit secondary antibody (Santa Cruze, USA).

Statistical analysis. SPSS 13.0 software was used for statisti$\mathrm{cal}$ analysis. The Pearson Chi's square test was used to examine the various clinicopathological characteristics of LGR5 positive and negative expression. Paired t-tests were used to analyze differences in LGR 5 expression between colon cancer and matched normal colonic mucosal tissue in patients and mice model. Unpaired t-tests were used to analyze the association between LGR 5 expression and clinicopathological parameters in patients. Survival analysis was conducted according to the Kaplan-Meier method, and the difference between the survival curves was analyzed with the log-rank test. Differences were considered significant if the probability of the difference occurring by chance was less than 5 in $100(\mathrm{p}<0.05)$.

\section{Results}

LGR5 mRNA and protein expression in patients and mice model. LGR5 protein and mRNA expression were investigated by immunohistochemistry and RT-PCR in human specimens which included adenoma, invasive neoplasms with lymph node metastasis and in murine adenocarcinoma. As shown in Figure 1 (A-G), LGR5 protein was highly expressed in $193(53 \%)$ of the colon carcinoma patients and 24 (60\%) of mice with colon cancer. The expression of LGR5 protein was found mostly in the cytoplasm of cancerous cells, of which some have membrane staining. The result were consistent with the one of LGR5 RNA expression in human and mice samples. As shown in Figure 1 (H, I), In human specimens (Figure1H), The samples with high LGR5 protein expression showed the level of LGR5 mRNA expression was as four times higher as that of matched in normal mucosal tissues. In mice model (Figure1I), primary colon cancer with elevated LGR5 protein expression in mice exhibited LGR5 mRNA expression at 6 times higher than that of the matched normal mucosal tissues.

Correlation between LGR5 mRNA expression and clinicopathology in patients or LGR5 mRNA and tumor size in mice model. LGR5 gene expression was analyzed clinicopathologically between colon cancer and matched normal mucosa in patients (Table1). LGR5 mRNA expression was

Table 2. primer sequences used for real-time PCR analysis.

\begin{tabular}{lcc}
\hline Gene & \multicolumn{1}{c}{ Primer sequence } & NCBI Accession Number \\
\hline Human LGR5 & CTCCCAGGTCTGGTGTGTTG & NM 003667.2 \\
& GAGGTCTAGGTAGGAGGTGAAG & NW 004078021.1 \\
Human GAPDH & TGTGGGCATCAATGGATTTGG & \\
Mice LGR5 & ACACCATGTATTCCGGGTCAAT & NW 004078029 \\
& ACATTCCCAAGGGAGCGTTC & \\
Mice GAPDH & ATGTGGTTGGCATCTAGGCG & NW 004077990.1 \\
& AATGGATTTGGACGCATTGGT & \\
\hline
\end{tabular}



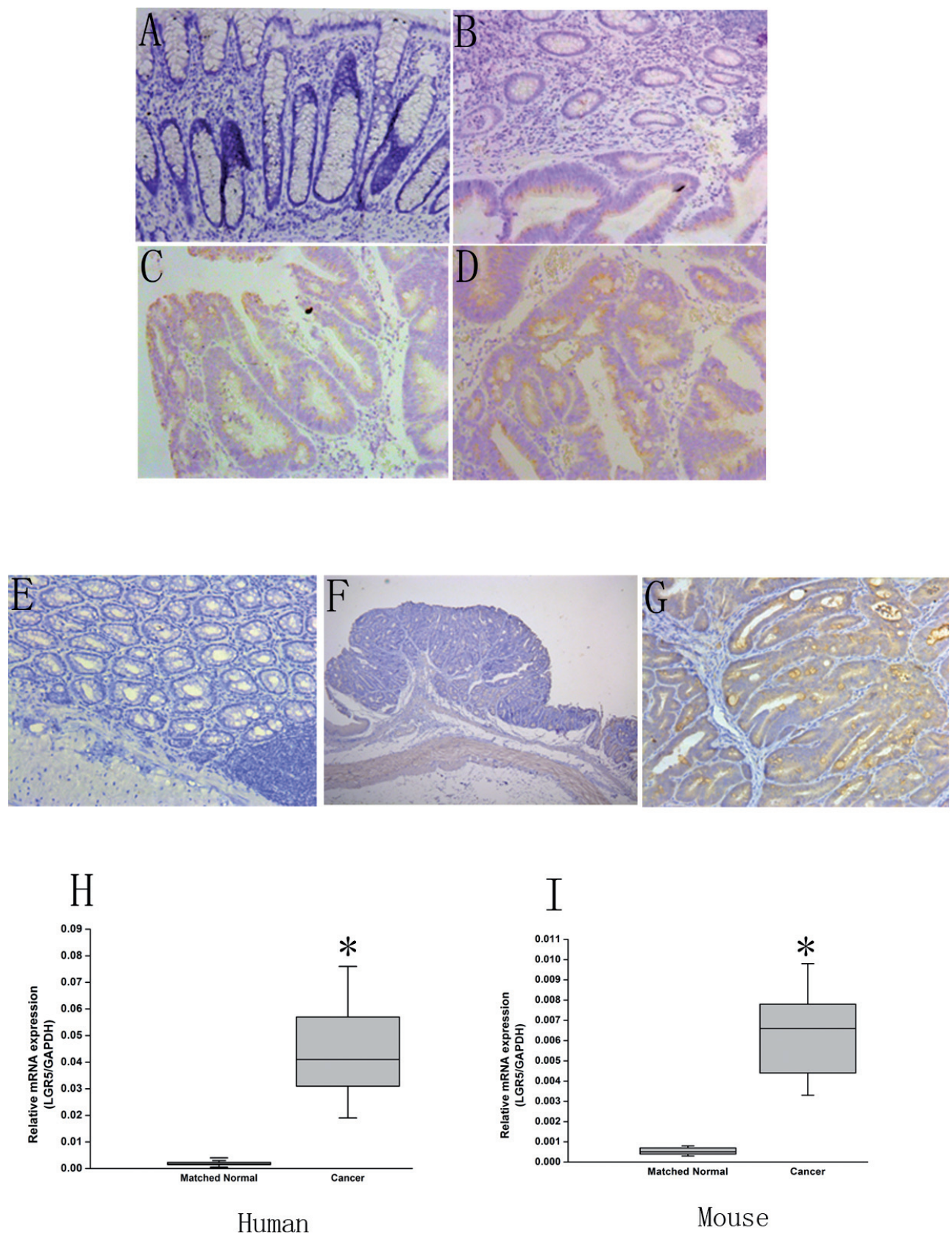

Figure 1. Detection of LGR5 gene and protein expression in different progression stages of colon cancer patients (B,C,D,H) and mice tumors (G,I). Compared with normal colon (A), LGR5 protein was immunohistochemically expressed in the membrane and cytoplasm of cancer cells in adenoma (B), carcinoma with lymph node metastasis (C), locally advanced carcinoma (D) of patients specimen. In mice, after ten months following AOM injections, colon tumors stained in HE (F) were developed and found overexpression of LGR5 (G) compared with normal mouse colon.LGR5 mRNA expression was measured by RT-PCR in patients (H) and in mice (I) compared with corresponded matched tissues. A-G Original magnificationsX400

measured between cases with positive and negative lymph node metastasis,pT4 and pT3 cases, and other features such as age, gender and location. As was shown in Figure2A, the significance of the diversified expression of LGR5 in clinical progression of patients was evaluated. Compared with normal mucosa, the difference of LGR5 expression in cases without lymph node metastasis or cases with pT3 was not significant. Normalized to LGR5 expression of matched normal mucosa, LGR5 expression was significantly elevated in cases with lymph node metastasis and pT4 stage tumors. Furthermore, (Figure2B) in mice tumors, LGR5 mRNA expression was found to be significantly higher in mice with tumor size more 
A
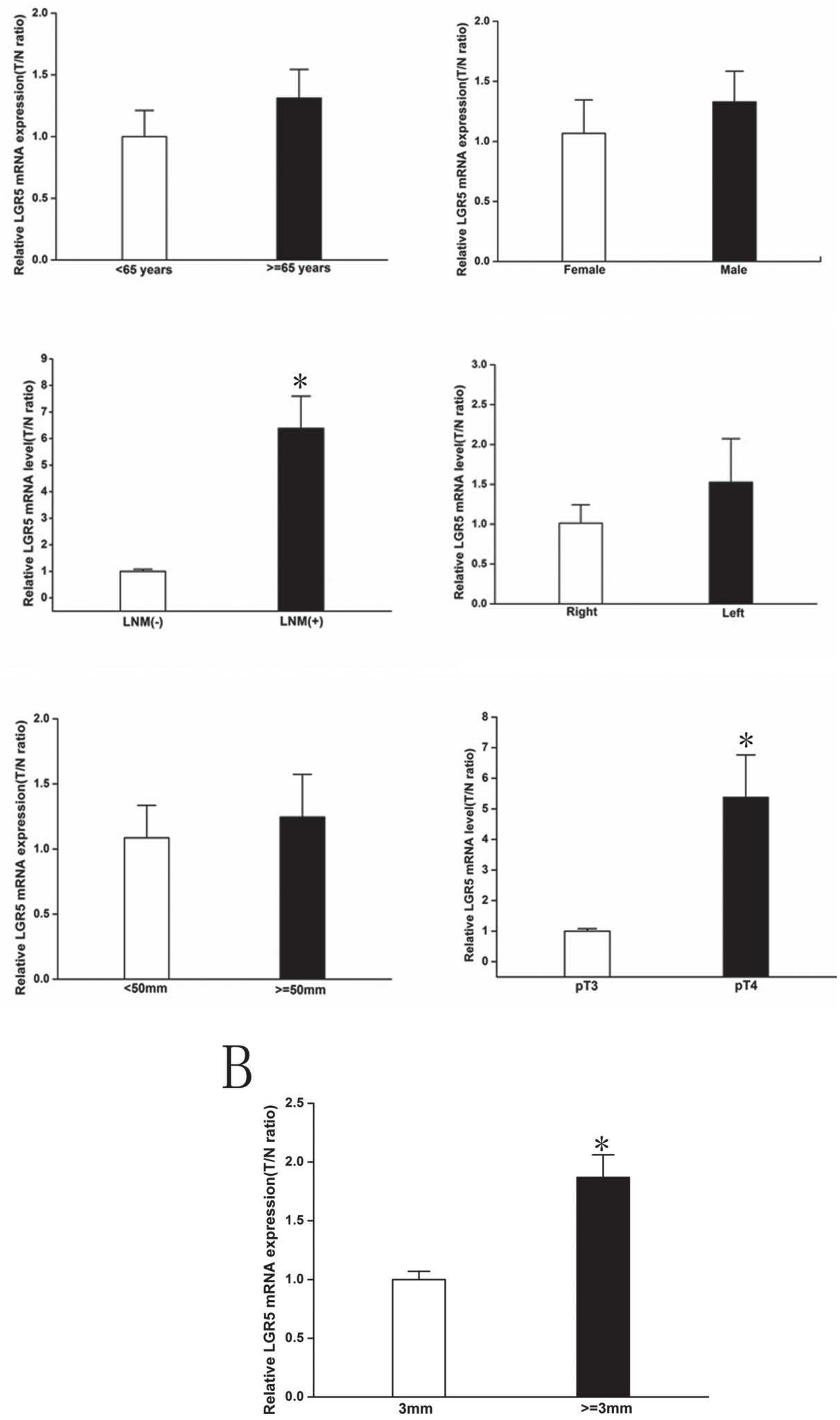

Figure 2. Correlation between Leucine-rich repeat-containing G protein-coupled receptor 5(LGR5) mRNA expression and clinicopathological findings in colon cancer patients and correlation between LGR5 mRNA and tumor size in mice model. 
than $3 \mathrm{~mm}$ diameter than those with less than $3 \mathrm{~mm}$. However, LGR5 expression was not associate with the age or gender of the patients.

Comparison of biomarkers PCNA and Ki67 for proliferation in LGR5 positive and negative cancer in patients and mice model. As shown in Figure 3A, No matter in patients or mice model, PCNA expression was markedly escalated in colon cancer compared with matched normal tissues. Moreover, colon cancer with positive LGR5 had significantly higher PCNA expression than those with negative LGR5. It was consistent with Ki67 expression in patients and mice tumors. As shown in Figure 3B. Ki67 expression in cancer was greatly higher than that in matched normal tissues and in LGR5 positive cancer was sharply increased than those with negative LGR5 cancer. All these showed LGR5 expression had close association with status of cell proliferation.

Survival analysis. As shown in Figure 4A, Survival analysis showed that the survival time of patients with LGR5 positive tumors was significantly shorter than those with LGR5 negative tumors. Nevertheless, The overall 5 -year survival rate of patients with LGR5 negative was significantly higher than those with LGR5 positive tumors.

A
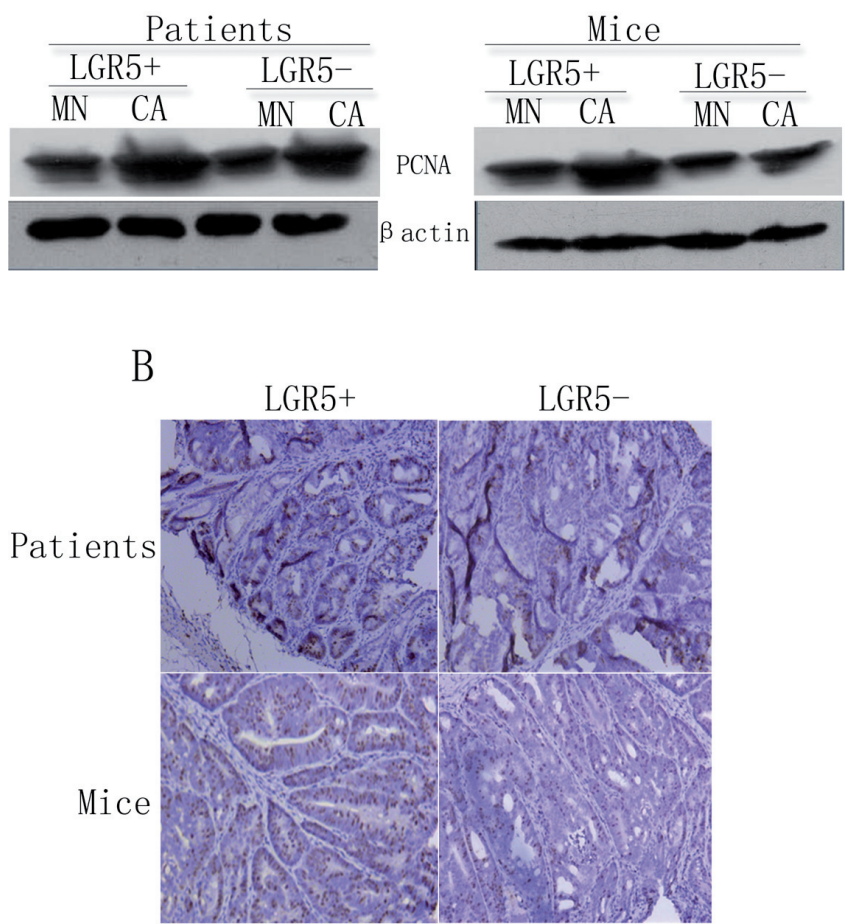

Figure 3. Detection of biomarkers for proliferation in colon cancer patients and mice model.(A) In human samples and micetumors, PCNA was determined by western blotting between LGR5 positive and negative cancer. (B) In human samples and mice tumors , Ki67 was evaluated by immunohistochemistry between LGR5 positive and LGR5 negative carcinoma.
(Figure 4B) In mice models, mice mucosal cancer with positive LGR5 protein expression were found to survive approximately $25 \%$ shorter than those with negative LGR5 protein expression.

A

S urviva 1 Functions

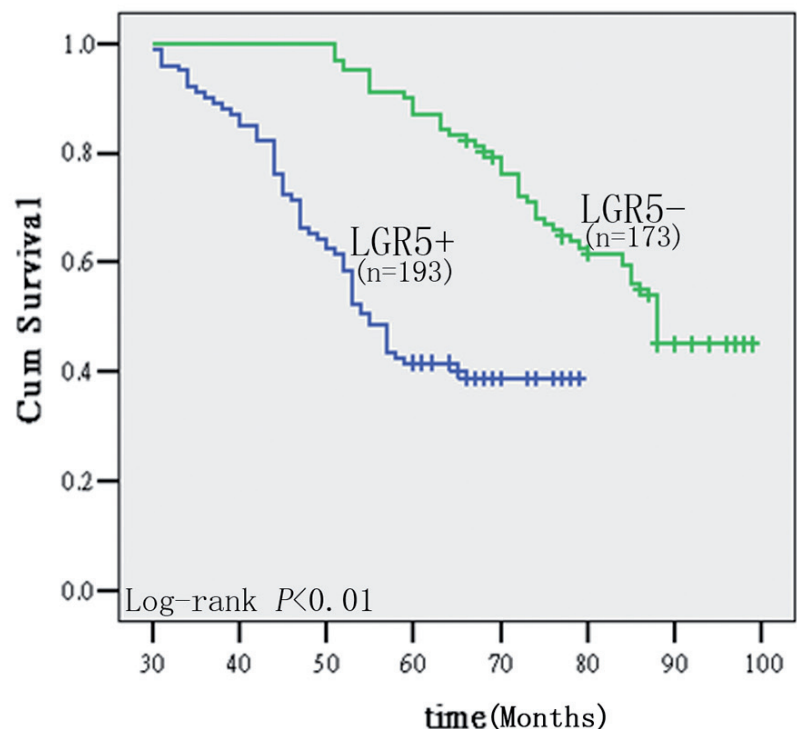

Patients

B

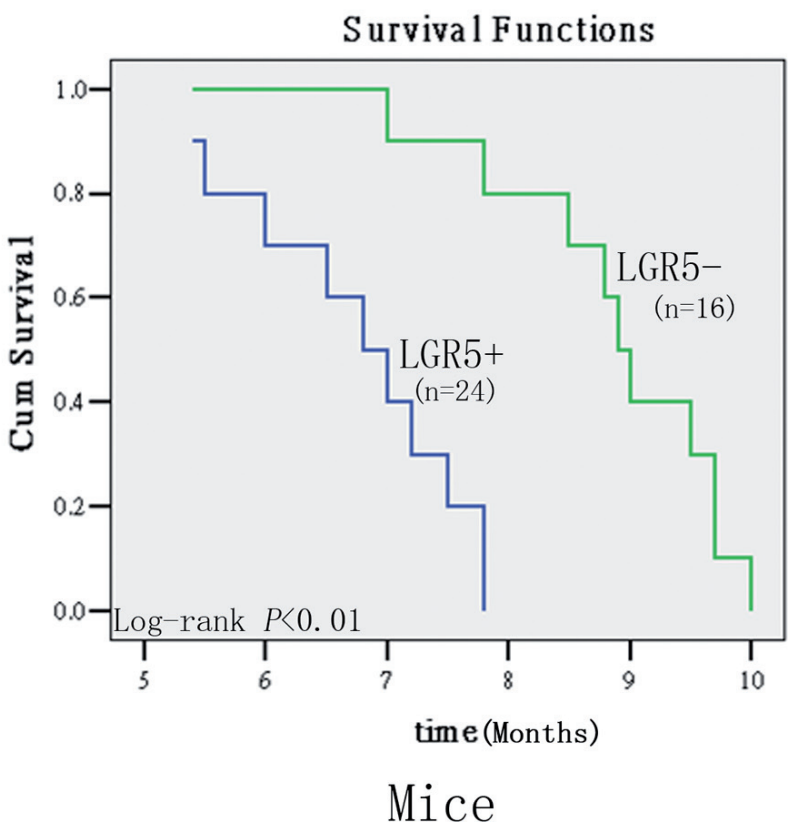

Figure 4. Kaplan-Meier survival analysis in LGR5 positive and negative cancer of patients and mice model. 


\section{Discussion}

Nowadays, strategies against cancers including surgical resection, radiotherapy and chemotherapy aim to induce cancer cell apoptosis,death,restrain cell growth and proliferation in various malignancies $[20,21]$. Yet, it still can not exterminate colon cancer relapse after a serial of treatments. Until now, the mechanism of tumor recurrence in colon cancer after cutative therapy has not been fully elucidated. But there is a widely accepted explanation for tumor reinitiation that the remnant of colon cancer stem cell has responsibility for relaps of tumors which have been removed or chemically compromised [22-24]. Therefore, colon cancer stem cells (CSCs) are the optimum targets for cure although the cellular origin of CSCs has not been clearly determined yet. It is well-known that GPCRs have been speculated to be closely correlated with CSCs during tumorigenesis $[25,26]$. LGR5, a member of the GPCR superfamily, is known as a putative marker for stem cells in the small and colon intestine. LGR5 over-expression has been found in cancer cells lines including hepatocellular carcinoma, colorectal cancer, ovarian cancer. Inspired by those findings, we collected colon cancer samples and established mice model with primary colon cancer which demand five months duration for tumor generation, results showed that LGR5 mRNA and protein expression was significantly over-expressed in more than half number of colon cancer not only in patients but also in mice model with primary colon cancer correlated with matched normal tissues. It implied that over-expression of LGR5 might be a general characteristics of colon cancer in both human and animal. Studies in the past have showed LGR5-expressing columnar base crypt cells at positions 1-4 can be an origin of CSCs which can finally grow into a malignant neoplasia. All above suggest that the origin of colon cancer may be intestinal stem cells expressing LGR5.

Intriguingly, a few researches have showed LGR5 expression is greatly elevated in colon cancer cell lines isolated from metastatic tumors compared with those derived from primary tumors $[16,27,28]$. To discern the relationship between LGR5 expression and distant involvement in patients, by using human samples, we compared cases of colon cancer with lymph node metastasis with those with locally advanced cancer. Marked alteration in LGR5 gene expression was observed among colon cancer patients with lymph node metastasis compared with those with no distant implication. Moreover, significantly higher LGR5 gene expression was detected in pT4 cases than that in pT3 cases. At the same time, in mice with primary colon tumors, we observed that LGR5 gene expression in mice which tumor size was more than $1 \mathrm{~mm}$ was nearly twice as that in mice which tumor size was less than $1 \mathrm{~mm}$. These results indicated that LGR5 expression might be correlated with malignant potential of colon cancer. Since the function of LGR5 underlying in colorectal tumorigenesis remains unclear, further studies are required to amplify the details. Based on other researches and our results, we strongly hypothesized that colon cancer patients with positive LGR5 expression might have higher tendency for progresion of the tumor than those with negative LGR5 expression because LGR5 expression had close relationship with progression of colon cancer. In current studies, we noticed that patients and mice with positive LGR5 expression were more vulnerable to die than those with negative LGR5 expression. LGR5 expression was associated with poor survival of colon cancer, indicated that LGR 5 positive cancer might grow and progress more quickly $[29,30]$. To investigate the proliferation of colon cancer cells, we tested PCNA and Ki67 of LGR5 positive and negative cancer in patients and mice model, which were markers for multiplication. Our study presented that in patients and mice model, colon cancer cells with positive LGR5 expression had higher level of PCNA and Ki67 expression than those with negative LGR5 expression.LGR5 expression was positively correlated with PCNA and Ki67, well-known nuclear antigen-specific markers of cellular propagation [31,32], suggested that LGR5-positive cancer cells had stronger proliferative activity. Taken together, we believed that LGR5 could be a promising prognostic biomarker in treatment of cancer patients, for with high LGR5 expression, patients with lymph node metastases or serious locally advanced have poor clinical outcomes after therapy. Thus, the quantity of LGR5 expression could be an indicator for adjuvant therapy in colon cancer patients.

Besides, in cancer recurrent patients, our observation found nearly half of them were overexpressed of LGR5. LGR5 positive stem cells which are remnant of colon cancer after treatment have reproductive capacity to form a new neoplasma. However, as to recurrent colon cancer with negative LGR5, what type of remnant stem cells or transit cells following therapy could afford to reproduction as LGR5 positive stem cell do? It remains to be further investigated.

In conclusion, LGR5, a putative intestinal stem cell marker, was frequently over-expressed in colon cancer cells in patients and mice model. It could provide some valuable and beneficial information to help predict the survival of patients with colon cancer. All findings manifest that LGR 5 takes on an important effect in the initiation and progression of colon neoplasm. However, there were several limitations in regard to interpretation and generalization of our findings. We had relatively small number of samples, which means we might broaden the prevalence of LGR5 expression in colon cancer cases. Another was no LGR5 knockout mice for the establishment of primary colon cancer. This transgenic mouse could be used to explore the possible function of LGR5 in the initiation and development of colon cancer. Further investigations are still needed to be performed to explore the relationship intensity between LGR5 and colon cancer.

Acknowledgments: We thank Honglian Ma, Shuaihua Li for providing technical assistance. This work was supported by Guangdong Province Natural Science Foundation(No.06021338) 


\section{References}

[1] FERLAY J, PARKIN DM, STELIAROVA-FOUCHER E. Estimates of cancer incidence and mortality in Europe in 2008. Eur J Cancer 2010; 46: 765-781. http://dx.doi.org/10.1016/ j.ejca.2009.12.014

[2] BJELAKOVIC G, NIKOLOVA D, SIMONETTI RG, GLUUD C. Systematic review: primary and secondary prevention of gastrointestinal cancers with antioxidant supplements. Aliment Pharmacol Ther 2008; 28: 689-703. http://dx.doi. org/10.1111/j.1365-2036.2008.03785.x

[3] JEMAL A, SIEGEL R, WARD E, MURRAY T, XU J, et al. Cancer statistics, 2007.CA Cancer J Clin 2007; 57: 43-66. http://dx.doi.org/10.3322/canjclin.57.1.43

[4] O'CONNELL JB, MAGGARD MA, KO CY. Colon cancer survival rates with the new American Joint Committee on Cancer sixth edition staging. J Natl Cancer Inst 2004; 96: 1420-5. http://dx.doi.org/10.1093/jnci/djh275

[5] ZEKI SS, GRAHAM TA, WRIGHT NA. Stem cells and their implications for colorectal cancer. Nat Rev Gastroenterol Hepatol 2011; 8: 90-100. http://dx.doi.org/ 10.1038/nrgastro.2010.211

[6] TEJPAR S, BERTAGNOLLI M, BOSMAN F, LENZ HJ, LYNCH HT, et al. Colorectal cancer. Lancet 2010; 375: 1030-47. http://dx.doi.org/10.1016/S0140-6736(10)60353-4

[7] MERLOS-SUAREZ A, BARRIGA FM, JUNG P, IGLESIAS M, CESPEDES MV, et al. The intestinal stem cell signature identifies colorectal cancer stem cells and predicts disease relapse. Cell stem cell2011; 8: 511-524. http://dx.doi.org/10.1016/ j.stem.2011.02.020

[8] RICCI-VITIANI L, LOMBARDI DG, PILOZZI E, BIFFONI $\mathrm{M}$, TODARO $\mathrm{M}$, et al. Identification and expansion of human colon-cancer-initiation cells. Nature 2007; 445: 111-115. http://dx.doi.org/10.1038/nature05384

[9] KELLEY SY, LUIS AC, XING NL,AKIFUMI O, JAMES S, et al. the intestinal stem cell markers Bmil and Lgr5 identify two functionally distinct populations. PNAS 2012; 109: 466-471. http://dx.doi.org/10.1073/pnas.1118857109

[10 VAN DER FLIER LG, SABATES-BELLVER J, OVING I, HAEGEBARTH A, DE PALO M, et al. The intestinal Wnt/TCF signature. Gastroenterology 2007; 132: 628-32. http://dx.doi. org/10.1053/j.gastro.2006.08.039

[11] SEGDITSAS S, SIEBER O, DEHERAGODA M, EAST P, ROWAN A, et al. Putative direct and indirect Wnt targets identified through consistent gene expression changes in APC-mutant intestinal adenomas from humans and mice. Hum Mol Genet2008; 17: 3864-75. http://dx.doi.org/10.1093/ $\underline{\mathrm{hmg} / \mathrm{ddn} 286}$

[12] YAMAMOTO Y, SAKAMOTO M, FUJII G, TSUIJI H, KENETAKA K, et al. Overexpression of orphan G-proteincoupled receptor, Gpr49, in human hepatocellular carcinomas with beta-catenin mutations. Hepatology 2003; 37: 528-33. http://dx.doi.org/10.1053/jhep.2003.50029

[13] BARKER N, VAN ES JH, KUIPERS J, KUJALA P, VAN DEN BORN M, et al. Identification of stem cells in small intestine and colon by marker gene Lgr5. Nature 2007; 449: 1003-1007. http://dx.doi.org/10.1038/nature06196
[14] BARKER N, HAN C. Tracking down the stem cells of the intestine: strategies to identify adult stem cells. Gastroenterology 2007; 133: 1755-1760. http://dx.doi. org/10.1053/i.gastro.2007.10.029

[15] AOKI D, SUZUKI N, SUSUMU N, NODA T, SUZUKI A, et al. Establishment and characterization of the RMG-V cell line from human ovarian clear cell adenocarcinoma. Hum cell 2005; 18: 143-6. http://dx.doi.org/10.1111/j.1749-0774.2005. tb00004.x

[16] HIROSHI U, KEN Y, MARIKO F, TAKETO Y, TETSU H, et al. Overexpression of leucine-rich repeat-containing $\mathrm{G}$ protein-coupled receptor 5 in colorectal cancer. Cancer Science 2010; 101: 1731-1737. http://dx.doi.org/10.1111/j.13497006.2010.01571.x

[17] TANESE K, FUKUMA M, YAMADA T, MORI T, YOSHIKAWA T, et al. G-protein-coupled receptor GPR49 is up-regulated in basal cell carcinoma and promotes cell proliferation and tumor formation. Am J Pathol2008; 173: 835-43. http://dx.doi. org/10.2353/ajpath.2008.071091

[18] BARKER N, RIDGWAY RA, VAN ES JH, VAN DE WETERING M, BEGTHEL $\mathrm{H}$, et al. Crypt stem cells as the cells-of-origin of intestinal cancer. Nature. 2009; 457: 608-612. http://dx.doi.org/10.1038/nature07602

[19] QIU W, CARSON-WALTER EB, LIU H, EPPERLY M, GREENBERGER JS, et al. PUMA regulates intestinal progenitor cell radiosensitivity and gastrointestinal syndrome. Cell Stem Cell 2008; 2: 576-83. http://dx.doi.org/10.1016/ j.stem.2008.03.009

[20] CHANG F, LEE JT, NAVOLANIC PM, STEELMAN LS, SHELTON JG, et al. Involvement of PI3K/Akt pathway in cell cycle progression, apoptosis, and neoplastic transformation: a target for cancer chemotherapy. Leukemia 2003; 17: 590-603.http://dx.doi.org/10.1038/sj.leu.2402824

[21] BRINDLEY DN, LIN FT, TIGYI GJ. Role of the autotaxinlysophosphatidate axis in cancer resistance to chemotherapy and radiotherapy. Biochim Biophys Acta 2013; 1831: 74-85. http://dx.doi.org/10.1016/j.bbalip.2012.08.015

[22] FRANCK NY, SCHATTON T, FRANK MH. The therapeutic promise of the cancer stem cell concept. J Clin Invest 2010; 120: 41-50. http://dx.doi.org/10.1172/JCI41004

[23] TODARO M, FRANCIPANE MG, MEDEMA JP, STASSI G, et al. Colon cancer stem cells: promise of targeted therapy. Gastroenterology2010; 138: 2151-2162. http://dx.doi.org/ 10.1053/j.gastro.2009.12.063

[24] SAIQUSA S, TANAKA K, TOIYAMA Y, MATSUSHITA $\mathrm{K}$, KAWAMURA $\mathrm{M}$, et al. Gene expression profiles of tumor regression grade in locally advanced rectal cancer after neoadjuvant chemoradiotherapy. Oncol Rep 2012; 28: 855-61.

[25] GSCHWIND A, HART S, FISCHER OM, ULLRICH A. TACE cleavage of proamphiregulin regulates GPCR-induced proliferation and motility of cancer cells. EMBO J 2003; 22: 2411-21. http://dx.doi.org/10.1093/emboj/cdg231

[26] KUZUMAKI N, SUZUKI A, NARITA M, HOSOYA T, NAGASAWA A, et al. Multiple analyses of G-protein coupled receptor(GPCR) expression in the development of gefitinibresistance in transforming non-small-cell lung cancer. Plos 
One 2012; 7: e44368. http://dx.doi.org/10.1371/journal. pone. 0044368

[27] WU XS, XI HQ, CHEN L. LGR5 is a potential marker of colorectal carcinoma stem cells that correlates with patient survival. World Journal of Surgical Oncology 2012; 10: 244. http://dx.doi.org/10.1186/1477-7819-10-244

[28] KOBAYASHI S, YAMADA-OKABE H, SUZUKI M, NATORI O, KATO A, et al. LGR5-positive colon cancer stem cells interconvert with drug-resistant LGR5-negative cells and are capable of tumor reconstitution. Stem cells 2012; 30(12): 2631-44. http://dx.doi.org/10.1002/stem.1257

[29] SIMON E, PETKE D, BOGER C, BEHRENS HM, WARNEKE $\mathrm{V}$, et al. The spatial distribution of LGR5+ cells correlates with gastric cancer progression. Plos One 2012; 7: e35486. http://dx.doi.org/10.1371/journal.pone.0035486

[30] TAKEDA K, KINOSHITA I, SHIMIZU Y, MATSUNO Y, SHICHINOHE T, et al. Expression of LGR5, an intestinal stem cell marker, during each stage of colorectal tumorigenesis. Anticancer Res 2011; 31: 263-70.

[31] MAGA G, HUBSCHER U. Proliferating cell nuclear antigen(PCNA): a dancer with many partners. J Cell Sci 2003;1:116. 32.Kannouche PL, Wing J, Lehmann AR. Interaction of human DNA polymerase eta with monoubiquitinated PCNA: a possible mechanism for the polymerase switch in response to DNA damage. Mol Cell 2004; 14: 491-500. http://dx.doi.org/10.1016/S1097-2765(04)00259-X 